atlases and bibliographies for Africa, and established joint training centres for technical staff. In I9S5 it sponsored a Foundation designed to facilitate an exchange of visits between scientists and technicians in the different territories of Africa. But further consideration led it to give priority to a more specific programme of technical assistance for which F.A.M.A. was accordingly set up.

The primary objects of F.A.M.A. are to collect and disseminate information concerning offers of, and requests for, the provision of technical assistance by one member state to another. It is expected that such technical assistance will take three forms : (i) providing the services of experts, instructors, or advisers; (ii) training personnel; and (iii) supplying equipment for training and research purposes.

\title{
The Teaching of English in African Schools
}

A CONFERENCE on the teaching of English in African schools was held from 28 to 30 March I958, under the auspices of the Institute of Education of the University College of Rhodesia and Nyasaland. Papers were read on the Place of English in African Education; Problems and Progress in teaching English in African Primary Schools; Problems and Progress in teaching English in African Secondary Schools; the Future of African Languages; and the Southern Rhodesia African Literature Bureau. It was stressed that English must be taught early and thoroughly if the education we are giving to Africans in other subjects in the curriculum is to be anything but superficial. The vernacular too is important, not only because it carries the culture of the people but because it is also a vital link between the child and his background. The standard of vernacular teaching should be raised to at least the level of English teaching for those whose mother tongue is English. This would prove an effective means of helping Africans to learn to speak, to understand, and to write English better.

The Southern Rhodesia African Literature Bureau aims to supply literature for the growing numbers of literate Africans and to encourage African authorship. A reader-tesearch poll showed that 77 per cent. preferred their reading matter to be in English, 17 per cent. in Shona, and the remaining 6 per cent. in Sindebele. These results were not regarded as surprising but as an indication of the African's realization of the importance of a knowledge of English to extend his studies. Publishable manuscripts had been received in the vernacular from well-educated Africans who were fluent in English, and seemed to want to turn back to their own history and folk-lore only after they had achieved a full education in English along Western lines. Adult African reading preferences were shown in a list of subjects or themes arranged in order of popularity. Education, The Law, How Government Works, and Health came first; European Customs and Love Stories last; but it was thought that as education spreads, the need for entertainment will rise and the need for direct instruction fall.

Among the recommendations of the six study groups set up to examine various specialized aspects of the teaching of language were: that research and teaching of Bantu languages at University level be undertaken; that vacation courses in the teaching of spoken English be held at the University College for instructors in teacher-training schools and possibly for secondary school teachers; and that the possibility of African school broadcasts in English be investigated.

\section{Centre Interfacultaire d'Anthropologie et de Linguistique Africaines de l'Université Officielle du Congo Belge et du Ruanda-Urundi}

EN mars 1958, le Conseil d'Administration de l'Université officielle a décidé de créer au sein de l'Université à Élisabethville un Centre interfacultaire d'anthropologie et de linguistique africaines. 
Cette création a pour but d'aider les Africains et les Européens qui ont des responsabilités dans l'évolution politique, économique et sociale des divers pays de l'Afrique subsaharienne à acquérir la formation nécessaire à l'accomplissement de leur tâche.

Le programme du Centre s'adresse à différentes catégories d'étudiants. D'abord aux futurs chercheurs, Européens et Africains, qui se destinent à une carrière scientifique professionnelle dans l'une ou l'autre des disciplines des sciences humaines en Afrique; ensuite à des personnes qu'une formation universitaire déterminée conduit en Afrique et qui souhaitent, dans leurs activités, être particulièrement attentives aux problèmes humains; enfin à des étudiants étrangers ayant déjà des qualifications dans une discipline humaine et qui désirent s'orienter vers une spécialisation africaine en Afrique même.

Le Centre, dont les cours, donnés par neuf professeurs, se répartissent en trois spécialisations - anthropologie physique, anthropologie sociale et linguistique - délivre des diplômes de licencié et de docteur en anthropologie africaine. Le diplôme de licencié en anthropologie africaine, groupe linguistique, est l'équivalent, pour les langues africaines, d'un diplôme de licencié en philologie romane ou germanique pour les langues d'Europe occidentale.

$\mathrm{La}$ licence est accessible aux porteurs de certains diplômes de candidature et de licence délivrés par l'Université officielle; en outre, le Centre peut admettre l'équivalence de diplômes universitaires belges ou étrangers.

Les études de licence durent deux ans, mais la présence effective à Élisabethville peut être réduite à deux semestres pour les porteurs d'un autre diplôme de licence. L'épreuve de doctorat, qui ne peut être tentée qu'une année au moins après l'obtention du diplôme de licencié en anthropologie africaine, comporte la soutenance d'une dissertation originale et d'une thèse annexe.

Toute personne qui désire des renseignements complémentaires sur les inscriptions, conditions d'admission, programmes, etc. est prié de s'adresser au président du C.I.A.L.A., Université officielle du Congo Belge et du Ruanda-Urundi, B.P. no ${ }^{\circ} 825$, Élisabethville.

\section{The Northern Region Literature Agency, Nigeria}

The Northern Region Literature Agency in Nigeria, popularly known as N.O.R.L.A., was founded in 1954 and is subsidized by the Northern Region Government. Its policy is controlled by the 'Fight Against Ignorance Committee', consisting of the Ministers of Finance, Education, and Internal Affairs, and Mr. A. J. Carpenter, M.B.E., formerly Federal Adviser on Adult Education, is its director. The publications of N.O.R.L.A. are distributed through agents, of whom there are 50 or 60 in each Province, on a commission basis, and today every important village has a bookshop selling newspapers, periodicals, and books published by N.O.R.L.A. and other organizations. There are today thirteen newspapers : six in Hausa, and one each in Tiv, Yoruba, Fulfulde, Kanuri, Nupe, Igala, and Idoma. A paper for the Niger is to be published by the Agency in the near future and an existing Kano paper taken over. Nearly 85,000 copies of these newspapers are sold every fortnight. N.O.R.L.A. also publishes two monthly magazines, The World and Agolfir, which are mainly educational; their Hausa publications include plays written by local authors and travel books.

\section{The Howard University Library's African Collection}

A catalogue has recently been published of the African Collection in the Moorland Foundation of the Howard University Library, Washington, D.C. The work of compilation has been carried out mainly by students in the Program of African Studies at Howard University under the editorship of Dorothy B. Porter. The materials listed in the present volume are those which had been received up to June 1957 . They include 4,865 book entries, arranged alphabetically by countries or other political units, which are in turn grouped under 